\title{
Clinical profile of patients with abnormal uterine bleeding at a tertiary care hospital
}

\author{
Radha Nair $^{1 *}$, Mallikarjuna M. ${ }^{2}$ \\ ${ }^{1}$ Department of Obstetrics \& Gynaecology, Kerala Medical College, Mangod, Cherupulassery, Palakkad, Kerala, India \\ ${ }^{2}$ Department of Obstetrics \& Gynaecology, Mount Zion Medical College, Chayalode, Adoor, Kerala, India
}

Received: 28 October 2015

Accepted: 14 November 2015

\section{*Correspondence:}

Dr. Radha Nair,

E-mail: ramspsm@gmail.com

Copyright: $\odot$ the author(s), publisher and licensee Medip Academy. This is an open-access article distributed under the terms of the Creative Commons Attribution Non-Commercial License, which permits unrestricted non-commercial use, distribution, and reproduction in any medium, provided the original work is properly cited.

\section{ABSTRACT}

Background: Abnormal uterine bleeding is a very common gynecological condition that affects all age groups. One third of patients attending gynaecology OPD present with complaints of abnormal uterine bleeding. Bleeding is said to be abnormal when the pattern is irregular, abnormal duration ( $>7$ days), or menorrhagia or abnormal amount (>80 $\mathrm{ml} /$ menses).

Methods: All patients in the perimenopausal age group ( $45 \pm 5$ years) with symptoms of abnormal uterine bleeding presenting at department of OBG, Tertiary care centre during the study period were included in the study. Totally 50 study subjects were included in the study as this number of patients attended hospital during the study period. Results: The most common presenting symptom was pain abdomens (28\%) followed by dysmenorrhea (16\%), and back ache $(2 \%)$. The most common bleeding pattern was menorrhagia (64\%) followed by polymenorrhoea (28\%), metrorrhagia (18\%) and menometrorrhagia (8\%).

Conclusions: The entire bleeding pattern was more commonly associated with abnormal uterine bleeding.

Keywords: Abnormal uterine bleeding, Menorrhagia, DUB

\section{INTRODUCTION}

Abnormal uterine bleeding is defined as any bleeding pattern that differs in the frequency, duration and amount from a pattern observed during a normal menstrual cycle or menopause. It is a common problem having a long list of causes in different age groups. ${ }^{1}$

Abnormal uterine bleeding is the commonest presenting symptom and major gynaecological problem responsible for as many as one-third of all out patient gynaecologic visit. $^{2,3}$

Menorrhagia affects $10-30 \%$ of menstruating women at any one time, and may occur at some time during the perimenopause in up to $50 \%$ of women. ${ }^{4}$
Abnormal uterine bleeding is a very common gynecological condition that affects all age groups. One third of patients attending gynaecology OPD present with complaints of abnormal uterine bleeding. ${ }^{5}$ Bleeding is said to be abnormal when the pattern is irregular, abnormal duration ( $>7$ days), or menorrhagia or abnormal amount (>80 ml/menses). ${ }^{6}$

During climacteric, ovarian activity declines. Initially, ovulation fails, no corpus luteum forms, and no progesterone are secreted by the ovary. Therefore the premenopausal menstrual cycles are shortened, often anovulatory and irregular. The irregularity in menstrual cycle during perimenopause can be due to anovulation or to irregular maturation of follicles. ${ }^{7}$ The increased risk of endometrial hyperplasia and endometrial carcinoma is more evident in peri-menopausal and post-menopausal 
women with abnormal uterine bleeding. ${ }^{8}$ The varied pattern of endometrial changes attracted our attention in peri-menopausal and post-menopausal age so to study them in detail with the help of available clinical data.

\section{METHODS}

The study population consisted of patients in the perimenopausal age group ( $45 \pm 5$ years) presenting with abnormal uterine bleeding.

\section{Inclusion criteria}

1. Patients in the perimenopausal age group $(45 \pm 5$ years)

2. Abnormal uterine bleeding.

\section{Exclusion criteria}

1. Patients less than 40 years of age.

2. Patients with uterine bleeding due to intra-uterine devices.

3. Patients not giving their consent to participate in the study.

\section{Sample size}

All patients in the perimenopausal age group $(45 \pm 5$ years) with symptoms of abnormal uterine bleeding presenting at department of OBG, Tertiary care centre during the study period were included in the study

Sample size is based on level of precision; precision consists of significance level and allowable error. In this study $5 \%$ significance and $20 \%$ allowable error is considered. Totally 50 study subjects were included in the study as this number of patients attended hospital during the study period

\section{Method of sampling}

No sampling method adopted as all the study subject fitting to inclusion criteria were considered

\section{Method of collection of data}

Study tool

Pre tested semi structured Questionnaire. The Questionnaire was presented in the Department for critical review, following which necessary changes were made in the Questionnaire.

Data was collected using Pre tested semi structured Questionnaire which was filed by the investigator. The endometrial samples (endometrial curettage/ biopsy and hysterectomy specimens) sent to pathology laboratory were analysed.

These specimens are fixed in $10 \%$ formalin and gross morphology was recorded. Endometrial samples were hysterectomy specimens. These bits were placed in cassettes and kept in fixative and processed in the totally embedded and representative bits are taken from automatic tissue processor.

Paraffin tissue blocks were prepared and 3-4 micrometre thick sections were cut and stained with routine haematoxylin and eosin. A detailed histological study was carried out and the findings were noted. Statistical analysis was done.

\section{Data entry and analysis}

Using Micro soft excel and Statistical package for social sciences

\section{Ethical consideration}

The protocol designed for the present study was submitted to the Ethical committee, after getting clearance from Research committee. Verbal consent was also taken and Confidentiality of the data is maintained.

\section{RESULTS}

Table 1: Distribution based on age.

\begin{tabular}{|lll|}
\hline Age group & Frequency & Percentage \\
\hline $40-41$ years & 15 & 30.0 \\
\hline $42-43$ years & 03 & 06.0 \\
\hline $44-45$ years & 14 & 28.0 \\
\hline $46-47$ years & 04 & 08.0 \\
\hline $48-49$ years & 08 & 16.0 \\
\hline 50 years and above & 06 & 12.0 \\
\hline Total & 50 & 100 \\
\hline
\end{tabular}

It was found that highest proportion of patients were in the age group of $40-41$ years $(30 \%)$ followed by $44-45$ years $(28 \%), 48-49$ years $(16 \%), 50$ years $(12 \%)$ and 42 -43 years $(6 \%)$.

Table 2: Distribution based on age of menarche.

\begin{tabular}{|lll|}
\hline Age of menarche & Frequency & Percentage \\
\hline 11 years & 10 & 20.0 \\
\hline 12 years & 15 & 30.0 \\
\hline 13 years & 14 & 28.0 \\
\hline 14 years & 09 & 18.0 \\
\hline 16 years & 02 & 04.0 \\
\hline Total & 50 & 100 \\
\hline
\end{tabular}

In this study, $30 \%$ of patients attained the age of menarche at 12 years, $28 \%$ of patients attained the age of menarche at 13 years, $20 \%$ of patients attained the age of menarche at 11 years, $18 \%$ of patients attained the age of menarche at 14 years, $4 \%$ of patients attained the age of menarche at 16 years. 
Table 3: Distribution based on parity.

\begin{tabular}{|lll|}
\hline Parity & Frequency & Percentage \\
\hline Nulliparous & 02 & 04.0 \\
\hline Multiparous & 36 & 72.0 \\
\hline Grand multiparous & 12 & 24.0 \\
\hline Total & 50 & 100 \\
\hline
\end{tabular}

Among total study subjects, $72 \%$ were multiparous, $24 \%$ were grand multiparous and $4 \%$ nulliparous.

Table 4: Distribution based on menstrual cycles.

\begin{tabular}{|lll|}
\hline Menstrual cycle & Frequency & Percentage \\
\hline Regular & 38 & 76.0 \\
\hline Irregular & 12 & 24.0 \\
\hline Total & 50 & 100 \\
\hline
\end{tabular}

Table 5: Distribution based on bleeding pattern.

\begin{tabular}{|lll|}
\hline Bleeding pattern & Frequency & Percentage \\
\hline Menorrhagia & 32 & 64.0 \\
\hline Metrorrhagia & 09 & 18.0 \\
\hline menometrorrhagia & 04 & 08.0 \\
\hline Oligomenorrhea & 00 & 00 \\
\hline Polymenorrhoea & 14 & 28.0 \\
\hline
\end{tabular}

Table 6: Distribution based on other complaints.

\begin{tabular}{|lll|}
\hline Complaints & Frequency & Percentage \\
\hline Pain abdomen & 14 & 28.0 \\
\hline Dysmenorrhea & 08 & 16.0 \\
\hline Back ache & 01 & 02.0 \\
\hline Generalized weakness & 01 & 02.0 \\
\hline Mass per vagina & 01 & 02.0 \\
\hline
\end{tabular}

Irregular cycles were found in $24 \%$ of patients.

Table 7: Comparative study of age incidence.

\begin{tabular}{|c|c|c|c|c|c|c|c|c|c|c|c|}
\hline \multirow{2}{*}{ Authors } & \multirow[t]{2}{*}{ No } & \multirow{2}{*}{$\begin{array}{l}<20 \\
\text { Total }\end{array}$} & \multicolumn{3}{|c|}{$21-30$} & \multirow{2}{*}{$\begin{array}{r}31-40 \\
\text { Total }\end{array}$} & \multicolumn{3}{|c|}{$41-50$} & \multicolumn{2}{|c|}{51 and above } \\
\hline & & & $\%$ & Total & $\%$ & & $\%$ & Total & $\%$ & Total & $\%$ \\
\hline $\begin{array}{l}\text { Sutherland }{ }^{9} \\
(1950)\end{array}$ & 1000 & 36 & 3.6 & 242 & 24.2 & 343 & 34.3 & 362 & 36.2 & 17 & 1.7 \\
\hline $\begin{array}{l}\text { Anusuya Das }{ }^{10} \\
\text { (1964) }\end{array}$ & 117 & 17 & 14.5 & 24 & 20.5 & 33 & 28.2 & 38 & 32.5 & 5 & 4.3 \\
\hline $\begin{array}{l}\text { Bhattacharji }{ }^{11} \\
\text { (1964) }\end{array}$ & 164 & 14 & 8.5 & 50 & 30.5 & 56 & 34.2 & 44 & 26.8 & - & - \\
\hline $\begin{array}{l}\text { Wagh and } \\
\text { Swamy } \\
\text { (1964) }\end{array}$ & 552 & 97 & 17.6 & 215 & 39 & 143 & 25.9 & 94 & 17 & 3 & 0.5 \\
\hline $\begin{array}{l}\text { Mehrotra }^{13} \\
(1972)\end{array}$ & 150 & 15 & 10 & 72 & 48 & 35 & 23.3 & 25 & 16.7 & 3 & 2 \\
\hline $\begin{array}{l}\text { Muzaffar } \\
(2005)\end{array}$ & 260 & 0 & 0 & 33 & 12.7 & 102 & 39.2 & 125 & 48.1 & - & - \\
\hline $\begin{array}{l}\text { Saraswathi }{ }^{15} \\
(2011)\end{array}$ & 409 & 6 & 1.5 & 85 & 20.8 & 116 & 28.4 & 137 & 33.5 & 65 & 15.8 \\
\hline Present & 50 & & & & & & & 44 & 88 & 06 & 12 \\
\hline
\end{tabular}

The most common bleeding pattern was menorrhagia (64\%) followed by polymenorrhoea $(28 \%)$, metrorrhagia $(18 \%)$ and menometrorrhagia (8\%) (Table 5).

The most common presenting symptom was pain abdomens (28\%) followed by dysmenorrhea (16\%), and back ache (2\%) (Table 6).

\section{DISCUSSION}

Abnormal uterine bleeding continues to be one of the most common and perplexing problems in gynaecological practice. It may present at any age between puberty and menopause. The highest incidence of AUB was noted in the 41-50years age group in the present study which is in concordance with the results of the studies by Anusuya
Das and Bhattacharji whereas Sutherland, Muhammed Muzaffar, Doraiswami Saraswathi reported maximum incidence in 41-50 years age group and Mehrotra et al, Wagh and Swamyand Dawn reported maximum incidence in 21-30 years age group. ${ }^{10-16}$

Considering these discrepant observations, one may conclude that, any age after menarche is not exempt from AUB. The highest incidence of AUB was seen in the reproductive age group (21-40 years) in the present study $(60.5 \%)$ which is in concordance with the results of the studies by Sutherland (58.5\%) and Mehrotra VG et al $(71.3 \%){ }^{9,13}$ 
Table 8: Parity and abnormal uterine bleeding.

\begin{tabular}{|lllll|} 
& \multicolumn{2}{l}{ Sadia Khan } & \multicolumn{2}{l|}{ Present study } \\
\hline Parity & Number & $\%$ & Number & $\%$ \\
\hline Nullipara & 27 & 5.4 & 02 & 4 \\
\hline Multi-para & 270 & 54 & 36 & 72 \\
\hline $\begin{array}{l}\text { Grand } \\
\text { multipara }\end{array}$ & 203 & 35.6 & 12 & 24 \\
\hline Total & 500 & 100 & 50 & 100 \\
\hline
\end{tabular}

Table 9: Comparative study of types of bleeding and AUB.

\begin{tabular}{|c|c|c|c|c|}
\hline \multirow[t]{2}{*}{ Type of bleeding } & \multicolumn{2}{|c|}{$\begin{array}{l}\text { Mehrotra } \\
\text { VG }^{13}\end{array}$} & \multicolumn{2}{|l|}{$\begin{array}{l}\text { Present } \\
\text { study }\end{array}$} \\
\hline & Number & $\%$ & Number & $\%$ \\
\hline $\begin{array}{l}\text { Heavy menstrual } \\
\text { bleeding } \\
\text { (Menorrhagia) }\end{array}$ & 78 & 52 & 32 & 64 \\
\hline $\begin{array}{l}\text { Inter menstrual } \\
\text { Bleeding } \\
\text { (Metrorrhagia) }\end{array}$ & 29 & 19.3 & 09 & 18 \\
\hline $\begin{array}{l}\text { Heavy \& prolonged } \\
\text { bleeding } \\
\text { (Menometrorrhagia) }\end{array}$ & 0 & 0 & 04 & 08 \\
\hline $\begin{array}{l}\text { Frequent menstrual } \\
\text { bleeding } \\
\text { (Polymenorrhoea) }\end{array}$ & 39 & 26 & 14 & 28 \\
\hline Oligomenorrhea & 0 & 0 & 00 & \\
\hline Total & 150 & 100 & 50 & 100 \\
\hline
\end{tabular}

In the present study, the highest incidence of AUB was seen in multiparous (72\%), which is in concordance with the results of the studies by Bhattacharji (46\%), Devi PK (48.6\%), Pillai (87\%), Joshi and Deshpande (61.5\%), Mehrotra VG et al (46\%) and Sadia K (54\%). ${ }^{11,13,17-20}$ The lowest incidence was seen in nulliparous women in the present study which is in concordance with the results of the studies by Mehrotra et al (20\%), Anusuya Das (18\%), Joshi and Deshpande (21.2\%), Bhattacharji (18.8\%) and Sadia K $(5.4 \%){ }^{10,11,13,17,20}$ By these observations, it may be implied that incidence of AUB is highest in parous women in general $87.5 \%$ and multipara in particular $58 \%$.

In the present study, heavy menstrual bleeding was the commonest type of bleeding (64\%) followed by intermenstrual bleeding (18\%), heavy and prolonged bleeding (8\%), frequent menstrual bleeding $(28 \%)$ and oligomenorrhea $(0 \%)$ in that order, whereas in the study by Mehrotra VG showed heavy menstrual bleeding was the commonest type of bleeding followed by frequent menstrual bleeding, inter menstrual bleeding and postmenopausal bleeding in that order. ${ }^{13}$

\section{CONCLUSIONS}

In this study, 40 - 41 years of age group, multiparity and menorrhagia were more commonly associated clinical presentations with Abnormal uterine bleeding.
Funding: No funding sources

Conflict of interest: None declared

Ethical approval: The study was approved by the Institutional Ethics Committee

\section{REFERENCES}

1. Dangal G. A study of endometrium of patients with abnormal uterine bleeding at Chitwan valley. Kathmandu University Medical Journal. 2003;1(2):110-2.

2. Khare A, Bansal R, Sharma S. Morphological spectrum of endometrium in patients presenting with dysfunctional uterine bleeding. People's Journal of Scientific Research. 2012;5(2):13-6.

3. Livingstone M, Fraser IS. Mechanisms of abnormal uterine bleeding. Human Reproduction Update. 2002;8(1):60-7.

4. Mirza T, Akram S, Mirza A, Aziz S, Mirza T, Mustansar T. Histopathological Pattern of Abnormal Uterine Bleeding in Endometrial Biopsies. J Basic and Applied Sciences. 2012;8:114-7.

5. Awwad JT, Toth TL, Schiff I. Abnormal Uterine Bleeding in the Perimenopause. International Journal of Fertility \& Menopausal Studies. 1993;38(5):2619.

6. Speroff L, Fritz MA. In: Clinical gynaecologic endocrinology and infertility. 7th edition. Jaypee Brothers Med Publishers (P) Ltd. Menopause and the peri-menopausal transition, 2005.

7. Padubidri VG, Daftary SN. Howkins and Bourne Shaw's Textbook of Gynaecology. 14th ed. Noida: Elsevier, A division of Reed Elsevier India Private Limited; 2008. Perimenopause, Menopause, Premature Menopause and Post-menopausal Bleeding. In: Padubidri VG, Daftary SN, editor. 2008: 52-62.

8. Kumar A, Mittal S. Endometrial sampling: How? \& why? Obs and Gynae Today. 2007;12(6):284-7.

9. Sutherland AM. Recent Advances in Obstetrics and Gynecology. Bourne A William JA. 1962: 365-381.

10. Anusuya D, Chugh S. Dysfunctional uterine Bleeding - A Clinico- pathological Study. J Obstet and Gynecol India. 1964;14(2):343-7.

11. Bhattacharji SK. Dysfunctional Uterine bleeding Correlation of endometrial pattern with clinical behavior. J Obstet Gynecol India. 1964;14(2):372-9.

12. Wagh KV, Swamy V. Functional uterine Haemorrhage. J Obstet and Gynecol India. 1964;14:87-392.

13. Mehrotra VG, Mukerjee K, Pandey M, Samanth V. Functional uterine bleeding (A review of 150 cases). J Obstet Gynaecol India. 1972;22:684-9.

14. Muzaffar M, Akhtar KAK, Yasmin S, Mahmood-urRehman, Iqbal W, Khan MA. Menstrual Irregularities with excessive blood loss: a ClinicoPathological Correlation. J Pak Med Assoc. 2005;55(11):486-9.

15. Saraswathi D, Thanka J, Shalinee R, Aarathi R, Jaya V, Kumar PV. Study of Endometrial Pathology in 
Abnormal Uterine Bleeding. Journal of Obstetrics and Gynecology of India. 2011;61(4):426-30.

16. Dawn CS. Environment and dysfunctional uterine haemorrhage. J Obstet Gynaecol India. 1964;14:40812.

17. Khan S, Hameed Sadia Ghani NA, Abdulrazak AA, Abdullah EM. Abnormal uterine bleeding: A histopathological study. World Res J Pathol. 2012;1(1):6-8.

18. Sanyal MK, Sanyal S, Bhattacherjee KK, Roy NN. Clinicopathological study of endometrium: A thousand nine hundred twenty cases in different abnormalities. J Obstet Gynaecol India. $1981 ; 31(5): 816-21$
19. Pillai GS, Sethi B, Dhaded AV, Mathur PR. Dysfunctional Uterine Bleeding (Study of 100 cases). J Obstet Gynaecol India. 2002;52(3):87-9.

20. Joshi SK. Atypical uterine bleedingHistopathological audit of endometrium A study of 638 cases. Al Ameen J Med Sci. 2013;6(1):21-8.

Cite this article as: Nair R, Mallikarjuna M. Clinical profile of patients with abnormal uterine bleeding at a tertiary care hospital. Int J Reprod Contracept Obstet Gynecol 2015;4:1753-7. 